\title{
Genetic and Pharmacological Evidence for More Than One Human Steroid $5 \alpha$-Reductase
}

\author{
Elizabeth P. Jenkins, ${ }^{\star}$ Stefan Andersson, ${ }^{\star}$ Julianne Imperato-McGinley, ${ }^{\star}$ Jean D. Wilson, and David W. Russell* \\ *Department of Molecular Genetics and $\$$ Internal Medicine, The University of Texas Southwestern Medical Center at Dallas, \\ Dallas, Texas 75235; and ${ }^{\ddagger}$ Department of Medicine, Cornell University School of Medicine, New York 10021
}

\begin{abstract}
The enzyme steroid $5 \alpha$-reductase catalyzes the conversion of testosterone into the more potent androgen, dihydrotestosterone, and impairment of this reaction causes a form of male pseudohermaphroditism in which genetic males differentiate predominantly as phenotypic females. We previously isolated cDNA clones that encode a human steroid $5 \alpha$-reductase enzyme. Here, we report molecular and genetic studies demonstrating that the gene encoding this cDNA is normal in subjects with the genetic disease steroid $5 \alpha$-reductase deficiency. We further show that in contrast to the major steroid $5 \alpha$-reductase in the prostate and cultured skin fibroblasts, the cDNA-encoded enzyme exhibits a neutral to basic pH optima and is much less sensitive to inhibition by the 4-aza steroid, finasteride (MK-906). The results provide genetic, biochemical, and pharmacological support for the existence of at least two steroid $5 \alpha$-reductase isozymes in man. (J. Clin. Invest. 1992. 89:293-300.) Key words: dihydrotestosterone • isozymes • androgens • 4-azasteroid inhibitors • pseudohermaphroditism
\end{abstract}

\section{Introduction}

The $5 \alpha$-reduction of testosterone (17 $\beta$-hydroxy-4-androsten-3one) to dihydrotestosterone (17 $\beta$-hydroxy-5 $\alpha$-androstan-3one) is crucial to androgen action. Dihydrotestosterone mediates virilization of a major portion of the male urogenital tract during embryogenesis and is responsible for most androgen effects during male puberty (1). The inborn error of metabolism that impairs this reaction causes a distinct form of male pseudohermaphroditism in which $46, \mathrm{XY}$ men have internal male wolffian duct structures, but female external genitalia $(2,3)$.

The $5 \alpha$-reduction of testosterone is catalyzed in rat and man by a membrane-bound, NADPH-dependent enzyme termed steroid $5 \alpha$-reductase $(1,4)$, but the number of enzymes that can effect this transformation is unknown. After the initial description of this enzyme (5), it was originally assumed that several steroid $5 \alpha$-reductase isozymes must exist, each of which preferentially uses a different steroid substrate (6). In agreement with this notion, steroid $5 \alpha$-reductase activities with different kinetic properties and $\mathrm{pH}$ optima were demonstrated in

Address correspondence to Dr. David W. Russell, Department of Molecular Genetics, University of Texas Southwestern Medical Center, 5323 Harry Hines Boulevard, Dallas, TX 75235.

Received for publication 2 May 1991 and in revised form 30 August 1991.

J. Clin. Invest.

(c) The American Society for Clinical Investigation, Inc.

0021-9738/92/01/0293/08 \$2.00

Volume 89, January 1992, 293-300 human tissues (7-9), and one of these activities appeared to be absent in patients with steroid $5 \alpha$-reductase deficiency (10). However, the fact that the $5 \alpha$-reduction of all steroid hormones is impaired in these patients (2), suggested that one enzyme is responsible for this activity. Further insight into the existence and function of steroid $5 \alpha$-reductase isozymes has been hampered by the low levels of enzyme activity expressed in tissues and by the profound insolubility of the protein $(1,4)$.

We have reported the isolation of rat and human steroid $5 \alpha$-reductase cDNAs $(11,12)$. In the rat, nucleic acid hybridization experiments provided evidence that the same steroid $5 \alpha$ reductase mRNA and gene were expressed in both the prostate and the liver (11). Expression of this gene in the regenerating prostate was shown to be regulated by androgens (11), and transfection of the cDNA into simian COS cells resulted in the synthesis of a steroid $5 \alpha$-reductase enzyme that was active against a wide variety of substrates and that was inhibited by 4-aza steroid compounds such as $17 \beta-N$-t-butyl-carbamoyl-4aza-5 $\alpha$-androst-1-en-3-one (finasteride, MK-906) (12). On balance, these data suggest that steroid $5 \alpha$-reduction in the rat can be mediated by the action of a single enzyme.

Studies with the human cDNA demonstrate the existence of both a functional steroid $5 \alpha$-reductase gene and a nonfunctional pseudogene (13). Chromosomal mapping experiments indicate that the functional gene is present on chromosome 5 , while the pseudogene is on the $X$ chromosome (13). Two restriction fragment length polymorphisms (RFLPs) ${ }^{1}$ in the functional gene segregate in a co-dominant fashion (13). When the human cDNA is expressed in mammalian cells, the resulting steroid $5 \alpha$-reductase catalyzes the reduction of a variety of substrates with $\Delta^{4}, 3$-keto structures; however, the enzyme is poorly inhibited by finasteride (12).

In this paper, we use molecular cloning, genetic, biochemical, and pharmacological approaches to study $(a)$ the relationship between the cloned human cDNA and steroid $5 \alpha$-reductase deficiency, and $(b)$ to compare the kinetic properties of the cDNA-encoded enzyme with the steroid $5 \alpha$-reductase activity expressed in human prostate. The data provide strong support for the existence of at least two steroid $5 \alpha$-reductase enzymes in man.

\section{Methods}

Materials. Enzymes for Southern blotting, RFLP analysis, and DNA sequencing were obtained from New England Biolabs, Beverly, MA; Amersham Corp., Arlington Heights, IL, and United States Biochemical Corp., Cleveland, OH. Nylon membranes were obtained from ICN Pharmaceuticals, Costa Mesa, CA (Biotrans), and Bio-Rad Laborato-

1. Abbreviation used in this paper: RFLP, restriction fragment length polymorphism. 
ries, Richmond, CA (Zeta-Probe). Thermus aquaticus(Taq) DNA polymerase was obtained from Perkin-Elmer Cetus, Norwalk, CT. $\left[\alpha-{ }^{32} \mathrm{P}\right]-$ $\operatorname{dCTP}(3,000 \mathrm{Ci} / \mathrm{mmol})$ and $\left[{ }^{14} \mathrm{C}\right]$ testosterone $(50-60 \mathrm{mCi} / \mathrm{mmol})$ were obtained from Du Pont-New England Nuclear, Boston, MA. $\left[\gamma-{ }^{32} \mathrm{P}\right]-$ $\operatorname{ATP}(7,000 \mathrm{Ci} / \mathrm{mmol})$ for 5 '-end-labeling of oligonucleotides was purchased from ICN Radiochemicals. Oligonucleotides were synthesized on DNA synthesizers (380A and 380B; Applied Biosystems, Foster City, CA). A thermocycler for use in polymerase chain reactions was obtained from Perkin-Elmer Cetus.

Fibroblast culture and Southern blotting. Fibroblasts from normal and steroid $5 \alpha$-reductase deficient subjects (Table I, refs. 14-19) were grown to confluency in 15-cm dishes before isolation of genomic DNA with a nucleic acid extractor (model 340A; Applied Biosystems). Human genomic DNA $(20 \mu \mathrm{g})$ was digested twice with a fivefold excess of restriction enzyme (BamHI, BglII, EcoRI, or HindIII) per microgram of DNA. The digested DNA was extracted with phenol/chloroform (1:1), and chloroform, and then made $0.3 \mathrm{M}$ in sodium acetate before precipitation with ethanol. Samples were electrophoresed, blotted, and subjected to hybridization with full-length $\mathrm{cDNA}$ probes as described by Lehrman et al. (20).

Polymerase chain reactions. Amplification (21) of individual or parts of exons was accomplished with the exon-specific oligonucleotide pairs listed in Table II. The locations of each oligonucleotide in the steroid $5 \alpha$-reductase gene are shown in Fig. 1. In a typical reaction, genomic DNA $(1 \mu \mathrm{g})$ was added to $100 \mu \mathrm{l}$ of a buffer $(10 \mathrm{mM}$ Tris-Cl, pH 8.3, $50 \mathrm{mM} \mathrm{KCl}, 1.5 \mathrm{mM} \mathrm{MgCl}, 0.01 \%$ (wt/vol) gelatin) containing the four deoxynucleoside triphosphates (1.25 mM each), and 20 $\mu \mathrm{M}$ of each oligonucleotide primer. If the amplified DNA was to be sequenced by the chemical method (22), one oligonucleotide per amplification reaction was first end-labeled with $\left[\gamma^{32}\right.$-P]ATP and bacteriophage T4 polynucleotide kinase (23). The thermocycler conditions used for the individual exons or fragments were as follows: exon $1,5^{\prime}$ or $3^{\prime}$ halves $=10 \mathrm{~min} / 94^{\circ} \mathrm{C}, 35 \mathrm{cycles}$ of $1 \mathrm{~min} / 94^{\circ} \mathrm{C}$ plus $3 \mathrm{~min} / 68^{\circ} \mathrm{C}, 10$ $\min / 68^{\circ} \mathrm{C}$; exons 2,3 , and $4=10 \mathrm{~min} / 94^{\circ} \mathrm{C}, 35$ cycles of $1 \mathrm{~min} / 94^{\circ} \mathrm{C}$ plus $30 \mathrm{~s} / 55^{\circ} \mathrm{C}$ plus $2 \mathrm{~min} / 72^{\circ} \mathrm{C}, 10 \mathrm{~min} / 72^{\circ} \mathrm{C}$; and exon $5=10 \mathrm{~min} /$ $94^{\circ} \mathrm{C}, 35$ cycles of $1 \mathrm{~min} / 95^{\circ} \mathrm{C}$ plus $5 \mathrm{~min} / 60^{\circ}, 10 \mathrm{~min} 60^{\circ} \mathrm{C}$. These reaction conditions were arrived at empirically. We were unsuccessful in amplifying exon 1 in its entirety despite the small size of this DNA ( $\sim 300 \mathrm{bp}$ ). For this reason, exon 1 was amplified in two halves as indicated above. Amplified DNA was purified on a neutral 5\% (wt/vol) polyacrylamide gel in a buffer containing $50 \mathrm{mM}$ Tris-borate, $\mathrm{pH} 8.3$ and $1 \mathrm{mM}$ EDTA, electroeluted, extracted with phenol/chloroform (1:1) and chloroform, and precipitated in ethanol containing $0.8 \mathrm{M}$ ammonium acetate before DNA sequence analysis or subcloning.

RFLP analysis. A Hinfl polymorphism present in exon 1 of the steroid $5 \alpha$-reductase gene was scored as described previously (13). Briefly, genomic DNA $(1 \mu \mathrm{g})$ corresponding to a portion of exon 1 containing the polymorphic site was amplified with oligonucleotides h5a35 and h5a36 (Table II) to yield a 210-bp fragment. After digestion with Hinfl, DNA was fractionated on a neutral polyacrylamide gel, transferred to Zeta-Probe membranes by electroblotting, and subjected to Southern blotting using a radiolabeled h5a35 probe (23). The presence of the Hinfl site leads to cleavage of the 210-bp fragment into a $5^{\prime}$ 138-bp fragment and a 3' 72-bp fragment. In Figs. 2 and 3, the h5a35 probe detects the starting 210-bp fragment if the Hinfl site is absent and the $5^{\prime} 138$-bp fragment if the site is present.

An Nsp 7524 I (NspI) polymorphism in exon 2 of the steroid $5 \alpha$-reductase gene was similarly detected by amplification of a 288-bp exon 2-containing fragment from genomic DNA using oligonucleotides h5a14 and h5a8 (Table II) followed by digestion with NspI (13). Restricted DNA was subjected to Southern blotting as described above, except that the radiolabeled probes corresponded to oligonucleotides h5a14 and h5a8. The presence of the site leads to cleavage of the 288-bp amplification product into a $5^{\prime} 137-\mathrm{bp}$ fragment and a $3^{\prime} 151$-bp fragment that are detected by $\mathrm{h} 5 \mathrm{a} 14$ and h5a8, respectively, in the autoradiograms of Figs. 2 and 3. Autoradiography to detect both RFLPs was carried out with Kodak $\mathrm{x}$-ray film (XRP-1) for 1-10 min at room temperature.

Table I. Clinical Information on Steroid 5 $\alpha$-Reductase Deficient Patients

\begin{tabular}{|c|c|c|c|c|c|c|c|c|}
\hline \multirow[b]{2}{*}{$\begin{array}{l}\text { Fibroblast } \\
\text { strain }\end{array}$} & \multirow[b]{2}{*}{ Initials } & \multirow[b]{2}{*}{ Origin } & \multirow[b]{2}{*}{ Consanguinity } & \multirow{2}{*}{$\begin{array}{l}\text { DNA } \\
\text { sequence }\end{array}$} & \multicolumn{2}{|c|}{ RFLP genotype* } & \multirow{2}{*}{$\begin{array}{l}\text { Enzyme } \\
\text { activity }\end{array}$} & \multirow[b]{2}{*}{ Reference } \\
\hline & & & & & Hinfl & NspI & & \\
\hline & & & & & & & $\mathrm{pmol} / \mathrm{mg}$ protein per $\mathrm{h}$ & \\
\hline 71 & C.C. & U.S. Black & No & Yes &,-- &,-- & $\begin{array}{l}\text { 3.0, abnormal } K_{\mathrm{m}} \text { for } \\
\text { NADPH, unstable enzyme }\end{array}$ & 16 \\
\hline 106 & M.U. & Sicily & No & Yes &,+- &,+- & $\begin{array}{l}\text { 0.6, abnormal } K_{\mathrm{m}} \text { for } \\
\text { NADPH and T }\end{array}$ & 17 \\
\hline 490 & M.M. & Malta & No & Yes &,++ &,++ & $\begin{array}{l}\text { 0.6, abnormal } K_{\mathrm{m}} \text { for } \\
\text { NADPH and T }\end{array}$ & 18 \\
\hline 667 & A.B. & Austria & No & Yes &,+- &,-- & $\begin{array}{l}\text { 1.6, abnormal pH optima, } \\
\text { abnormal } K_{\mathrm{m}} \text { for } \mathrm{T}\end{array}$ & 19 \\
\hline 526 & T.A. & Latvia & Yes & Yes &,+- &,+- & $<0.2$ & This study \\
\hline $526 \mathrm{~A}$ & J.A. & Latvia, father & Yes & No &,+- &,+- & ND & This study \\
\hline $526 \mathrm{~B}$ & V.A. & Latvia, mother & Yes & No &,+- &,-- & ND & This study \\
\hline 1 & S.J. & U.S. Black & No & No &,++ &,++ & $<0.2$ & 14 \\
\hline 2 & J.J. & U.S. Black & No & No &,+- &,+- & $<0.2$ & 14 \\
\hline 129 & W.J. & U.S. Black, father & No & No &,+- &,+- & ND & 14 \\
\hline 41 & M.C. & Dominican Republic & Yes & No &,+- &,-- & $<0.2$ & 15 \\
\hline 338 & F.Ç. & Dominican Republic & Yes & No &,-- &,-- & $<0.2$ & This study \\
\hline NG2 & Y.A. & New Guinea & Yes & No &,+- &,+- & $<0.2$ & 27 \\
\hline NG3 & I.K. & New Guinea & Yes & No &,++ &,+- & $<0.2$ & 27 \\
\hline NG4 & T.S. & New Guinea & Yes & No &,+- &,+- & $<0.2$ & 27 \\
\hline 904 & M.K. & Pakistan & Yes & No &,+- &,+- & $<0.2$ & This study \\
\hline
\end{tabular}

* $(+)$, presence of indicated site; $(-)$, absence of indicated site. The order of + and - symbols is arbitrary, as the phase of the RFLPs on chromosome 5 was not determined. ${ }^{\ddagger}$ Determined as described in reference 14 . $T$, testosterone. 


\begin{tabular}{|c|c|c|c|}
\hline Oligonucleotide & Location & $\begin{array}{l}\text { Amplification } \\
\text { target }\end{array}$ & Sequence $5^{\prime} \rightarrow 3^{\prime}$ \\
\hline h5a30 & Exon 1 & $5^{\prime}$ half Exon 1 & GGCCTCTGGGGCATGGAGCACGCTGCCCAGCCCTG \\
\hline h5a27 & Exon 1 & $5^{\prime}$ half Exon 1 & GGCACTCGGAGCCTGTGGCTGGGCA \\
\hline h5a2 & Exon 1 & $3^{\prime}$ half Exon 1 & GGAATCGTCAGACGAACTCAGTGTA \\
\hline h5a4 & Intron 1 & $3^{\prime}$ half Exon 1 & GTCGGAGAGGACGCCGGGCCGGGAG \\
\hline h5a14 & Intron 1 & Exon 2 & CCCAAATCATTTAAGATAGGATTAC \\
\hline h5a8 & Intron 2 & Exon 2 & ATGATGTGAACAAGGCGGAGTTCAC \\
\hline h5a9 & Intron 2 & Exon 3 & TGAAATTTTACGGTTTATTAGCCATAAT \\
\hline h5a19 & Intron 3 & Exon 3 & AGCAACTTTCACAGAAATTCTTCAC \\
\hline h5a 17 & Intron 3 & Exon 4 & CCGTATTTCATTTTGTAGTAAATGG \\
\hline h5a18 & Intron 4 & Exon 4 & TAGTCAAAGAACAAATTACAAATGG \\
\hline h5a20 & Intron 4 & Exon 5 & CATTGGTTAAATGTCTAAGCGACAG \\
\hline h5a12 & Exon 5 & Exon 5 & AAAGTCCATAGAGAAGCGCCATTGG \\
\hline h5a35 & Exon 1 & Hinfl RFLP Exon 1 & CAGGATCCGAGGCCTCTGGGGCATGGAGCACGCTGCCCAGCCCTG \\
\hline h5a36 & Exon 1 & Hinfl RFLP Exon 1 & CGAAGCTTCAGGCACTCGGAGCCTGTGGCTGGGCA \\
\hline
\end{tabular}

DNA sequencing. DNA sequencing by the chemical method was accomplished with the methods of Maxam and Gilbert (22). Both strands of the DNA corresponding to the individual exons of the steroid $5 \alpha$-reductase gene were sequenced from at least two independent amplification reactions. Dideoxy-mediated chain-termination DNA sequencing was carried out according to the methods of Sanger et al. (24) on exon-containing fragments subcloned into the bacteriophage M13 vectors mp18 and mp19 (ref. 25). For each exon of the steroid $5 \alpha$-reductase gene, three independent clones from each strand of the DNA were subjected to sequence analysis. DNA sequence data was analyzed on an IBM-PC AT computer using a MicroGenie program (Beckman Instruments, Inc., Fullerton, CA).

Steroid $5 \alpha$-reductase assay. The conversion of $\left[{ }^{14} \mathrm{C}\right]$ testosterone into dihydrotestosterone by steroid $5 \alpha$-reductase was assayed in a buffer containing $0.1 \mathrm{M}$ Tris- $\mathrm{Cl}$ and $0.1 \mathrm{M}$ sodium citrate and analyzed by thin-layer chromatography $(11,12)$. The reaction conditions used in individual experiments are described in the figure legends. Prostate tissue was obtained from subjects undergoing surgical treatment for benign prostatic hyperplasia from Dr. J. McConnell (Department of Internal Medicine, University of Texas Southwestern Medical Center, Dallas, Texas) and immediately frozen in liquid nitrogen and stored at $-70^{\circ} \mathrm{C}$. Prostate extracts were prepared by a modification of the procedures of Liang et al. (26). Briefly, a 5-g aliquot of frozen tissue was pulverized in liquid nitrogen in a mortar and then homogenized in 3 $\mathrm{vol}(\sim 15 \mathrm{ml})$ of $20 \mathrm{mM}$ potassium phosphate, $\mathrm{pH} 6.5,0.32 \mathrm{M}$ sucrose, $1 \mathrm{mM}$ EDTA with a polytron followed by a glass-Teflon Potter-Elve-

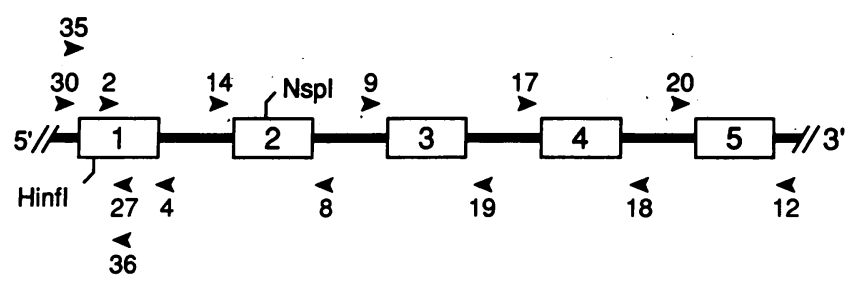

Figure 1. Schematic of steroid $5 \alpha$-reductase gene and location of oligonucleotide primers. The five exons of the gene are shown as numbered boxes connected by thick lines representing introns or $5^{\prime}$ and $3^{\prime}$ flanking regions. The locations and orientations of oligonucleotide primers used in amplification reactions are shown above and below the gene. The locations of polymorphic Hinfl and NspI sites are shown in exons 1 and 2, respectively. The gene schematic is not drawn to scale. hem homogenizer. The resulting homogenate was filtered through cheesecloth to remove fibrous particulate matter and then centrifuged for $1 \mathrm{~h}$ at $4^{\circ} \mathrm{C}$ at $100,000 \mathrm{~g}$. The membrane pellets from this centrifugation were resuspended in $\sim 15 \mathrm{ml}$ of the above buffer using a glassTeflon homogenizer and again collected by centrifugation. The final membrane pellets were resuspended at a protein concentration of 5-10

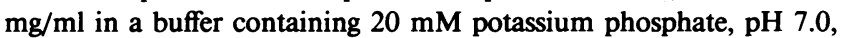
$20 \%$ (vol/vol) glycerol using the glass-Teflon homogenizer, and then stored at $-70^{\circ} \mathrm{C}$ in small aliquots. Transfection of cultured COS-M6 cells with a steroid $5 \alpha$-reductase expression vector and preparation of

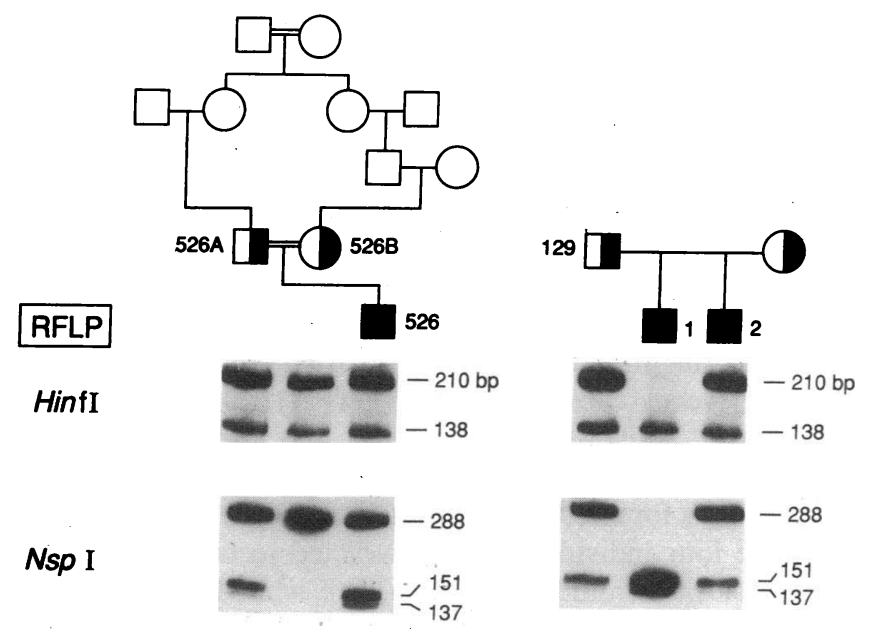

Figure 2. Absence of homozygosity at steroid $5 \alpha$-reductase locus in consanguineous family and different genotypes in a family with two affected individuals. On the left is shown a pedigree of a family in which multiple consanguineous matings have taken place. DNA was isolated from the obligate heterozygous father (526A, Table I) and mother (526B), and the homozygous affected child (526), and scored for the presence of Hinfl and NspI RFLPs in the steroid $5 \alpha$-reductase gene as described in Methods. An autoradiogram of the results is shown below the pedigree. The child is seen to be heterozygous for both RFLPs. On the right is shown a similar analysis of a family with two affected members (subjects 1 and 2, Table I). DNA was available for analysis from only one parent (the father, 129, Table I) of this family. The two affected individuals are seen to have different genotypes with respect to the Hinfl and NspI polymorphisms. 

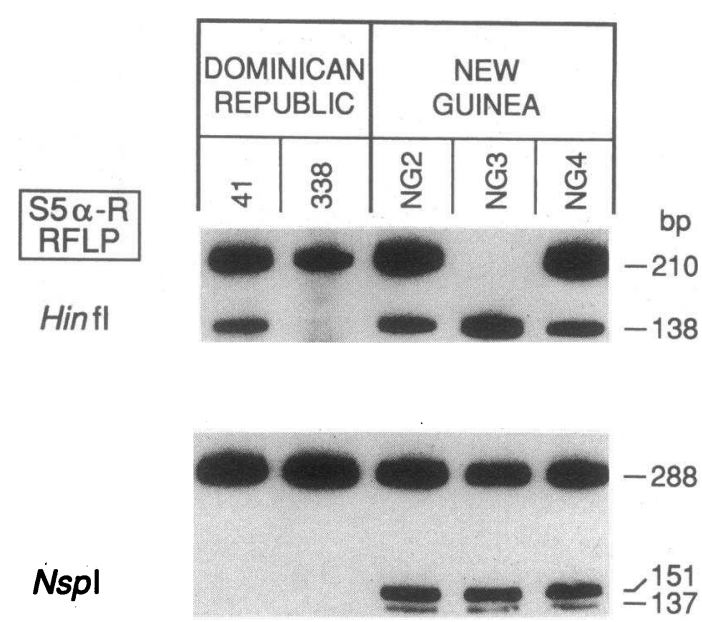

Figure 3. Absence of homozygosity at the steroid $5 \alpha$-reductase locus in affected individuals from geographically isolated populations. DNA was purified from two affected individuals from the Dominican Republic and from three affected individuals from the Simbari Anga tribe in the Highlands of Papua, New Guinea (27) and scored for the Hinfl and NspI polymorphisms as described in Methods. In the Dominican Republic samples, one individual is heterozygous for the Hinfl marker, while both subjects are homozygous for the absence of the NspI site. Heterozygosity for the Hinfl polymorphism is similarly present in two of the three New Guinea subjects, while all three of these individuals are heterozygous for the NspI polymorphism.

cell lysates containing the enzyme encoded by the cDNA were carried out as described by Andersson and Russell (12).

\section{Results}

To study the molecular genetics of steroid $5 \alpha$-reductase deficiency, we first collected and analyzed DNA from multiple affected individuals. As shown in Table I, the subjects studied were of different ethnic origins and included probands from geographically isolated populations, consanguineous marriages, and a family with multiple affected progeny. The levels of steroid $5 \alpha$-reductase enzyme activity in fibroblasts biopsied from these individuals varied from the low end of normal (1$100 \mathrm{pmol}$ dihydrotestosterone formed/mg protein per $\mathrm{h}$ ) to below the level of detection. One subject (71) expressed an unstable enzyme, while three subjects $(106,490$, and 667) expressed low levels of steroid $5 \alpha$-reductase activity that demonstrated altered $K_{\mathrm{m}}$ 's for testosterone and/or NADPH. The mutations in these four individuals were predicted to be in the coding region of the steroid $5 \alpha$-reductase gene, while those giving rise to the apparent null alleles could map throughout the gene.

Genomic DNA from each of the affected individuals of Table I was prepared and subjected to Southern blotting analysis after digestion with four restriction enzymes (EcoRI, BamHI, HindIII, and BglII). Hybridization was carried out with radiolabeled probes derived from either the full-length cDNA or from multiple exons of the cloned gene. No rearrangements were detected that altered the structure of the gene (data not shown), suggesting that if mutations were present, they would most likely be small rearrangements or point mutations.

The structure of the gene at the nucleotide level was examined by synthesizing a series of oligodeoxynucleotide primers for use in the polymerase chain reaction. Table II and Fig. 1 indicate the sequence and locations of the multiple primers that were used to amplify the five exons of the gene. Exon 1 was amplified in two halves, whereas exons 2 through 5 were amplified as individual DNA fragments. The locations of the primers were such that mutations in the coding region or at the $5^{\prime}$ or $3^{\prime}$ splice junctions could be detected (Fig. 1). For each pair of oligonucleotides, the optimal conditions for amplifying the target DNA from genomic DNA were established empirically with DNA from normal individuals.

All exons of the steroid $5 \alpha$-reductase genes of five subjects were amplified and subjected to DNA sequence analysis using both direct chemical sequencing methods and enzymatic methods after subcloning into bacteriophage $\mathrm{M} 13$ vectors. Inasmuch as a history of consanguinity was denied in four of these individuals $(71,106,490$, and 667 , Table I), it is possible that they were each compound heterozygotes possessing two mutant alleles at the steroid $5 \alpha$-reductase locus. A fifth subject (526) was the product of a consanguineous marriage, and presumably was a true homozygote who inherited the same mutant allele from both parents.

No mutations were detected that altered the coding region or splice junctions of any of the exons of these five subjects. Given the altered biochemical phenotypes of the enzyme in four of the individuals (Table I), these data suggest that mutations in the isolated gene were not responsible for steroid $5 \alpha$-reductase deficiency. To obtain further genetic evidence to support this hypothesis, we made use of two RFLPs that are present in the cloned gene, a polymorphic Hinfl site in exon 1 and a polymorphic NspI site in exon 2 (13, Fig. 1). All affected individuals were genotyped with respect to these two markers (Table I), and selected results are described below.

The left panel of Fig. 2 shows an analysis of steroid $5 \alpha$-reductase RFLPs in a pedigree with multiple consanguineous matings. Heterozygosity for both RFLPs was observed in the inbred affected offspring (subject 526, Table I) of a marriage between first cousins once removed. Similarly, subject 904 (Table I), a product of a consanguineous marriage, was also found to be heterozygous for both markers (data not shown). The right panel of Fig. 2 shows an analysis of family with two affected individuals (subjects 1 and 2, of Table I). The offspring are seen to have different genotypes with respect to the two RFLPs. One is homozygous for the presence of both the HinfI and NspI sites (i.e., both chromosomes have the scored restriction site), while the second is heterozygous for both markers (i.e., one chromosome has the scored restriction site, and the second chromosome lacks the site).

Fig. 3 shows the results of an RFLP analysis of affected individuals from two geographically isolated populations. Two individuals (subjects 41 and 338, Table I) were from a village in the Dominican Republic in which isolation and extensive consanguinity have been well documented (15). The left panel of Fig. 3 indicates that subject 41 is heterozygous for the presence of the Hinfl site, while subject 338 is homozygous for the absence of the site. Both individuals were homozygous for the absence of the NspI site. Three affected individuals (NG2, NG3, and NG4, Table I) from an isolated tribe in the highlands of New Guinea (27) were similarly found to have different genotypes. Subjects NG2 and NG4 were heterozygous for both RFLPs, while subject NG3 was homozygous for the presence of the HinfI site and heterozygous for the NspI site (Fig. 3, right panel). Taken together with the results of Fig. 2, the differing genotypes and absence of homozygosity observed in these RFLP studies provided convincing genetic evidence that muta- 
tions in the cloned gene do not underlie steroid $5 \alpha$-reductase deficiency. In turn, this conclusion suggested the presence of more than one steroid $5 \alpha$-reductase enzyme in human tissues.

To obtain further support for this hypothesis, we compared (Fig. 4) the pH optima of the steroid $5 \alpha$-reductase enzyme present in human prostate tissue to that of the enzyme encoded by the cDNA and gene analyzed in the subjects of Table I. As a source of the cloned enzyme, the steroid $5 \alpha$-reductase cDNA was transfected into simian kidney COS cells and allowed to express for $48 \mathrm{~h}$ before preparation and assay of cell lysates. The kinetics of the COS cell-expressed enzyme have been characterized previously (12) and endogenous COS cell steroid $5 \alpha$-reductase enzyme activity is below the level of detection in the assay system used (12). The cDNA-encoded enzyme was maximally active over a broad $\mathrm{pH}$ range $(6.0-8.5$, Fig. $4 A$ ). In contrast, the enzyme present in human prostate extracts exhibited a narrow pH optimum centered around 5.0 (Fig. $4 \mathrm{~B}$ ). These latter results agree well with those obtained previously in several laboratories $(7,9,10,26)$. In a separate experiment, when a COS cell extract containing the cloned enzyme was mixed with that derived from the prostate gland, two distinct peaks of activity were detected, one at $\mathrm{pH} 5.0$ and a second at approximately $\mathrm{pH} 7.0-8.0$ (Fig. 5). These results suggest that the presence of inhibitors or modifiers in either of the two extracts can not explain the steroid $5 \alpha$-reductase activities with acidic and basic pH optima.

The enzyme encoded by the cDNA is relatively insensitive $\left(K_{\mathrm{i}} \sim 300-600 \mathrm{nM}\right)$ to the 4-aza steroid inhibitor finasteride (MK-906) (12). In contrast, this compound inhibits the prostate enzyme with a $K_{\mathrm{i}}$ of $\sim 10 \mathrm{nM}$ (26). To compare the finasteride inhibition profiles of the two enzymes directly, we carried out the experiments shown in Figs. 6 and 7. First, the apparent $K_{\mathrm{i}}$ values (28) for finasteride were determined with

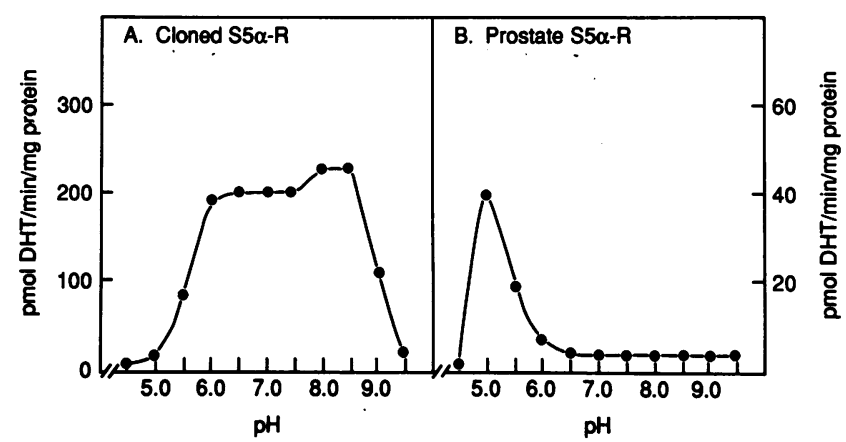

Figure 4. $\mathrm{pH}$ optima of the cDNA-encoded and prostate steroid $5 \alpha$ reductase activities. $(A)$ An expression vector containing the steroid $5 \alpha$-reductase cDNA was transfected into simian COS cells as described previously (12). $48 \mathrm{~h}$ after transfection, cells were harvested, lysed by homogenization with a polytron, and subjected to enzyme assay. $130 \mu \mathrm{g}$ of homogenate were assayed in a volume of $0.5 \mathrm{ml}$ for $20 \mathrm{~min}$ at $37^{\circ} \mathrm{C}$ in the presence of $10 \mu \mathrm{M}\left[{ }^{14} \mathrm{C}\right]$ testosterone and 10 $\mathrm{mM}$ NADPH at the indicated $\mathrm{pH}$. Assays were terminated by the addition of 10 volumes of dichloromethane and subjected to thin-layer chromatography analysis to determine the amount of dihydrotestosterone (DHT) product formed (11). (B) Prostate extracts were prepared as described in Methods. $400 \mu \mathrm{g}$ of protein were incubated in a volume of $0.5 \mathrm{ml}$ at $37^{\circ} \mathrm{C}$ with $10 \mu \mathrm{M}\left[{ }^{14} \mathrm{C}\right]$ testosterone for $30 \mathrm{~min}$ at the indicated $\mathrm{pH}$ before thin-layer chromatography analysis. For both panels A and B, the results are typical of at least two separate experiments.

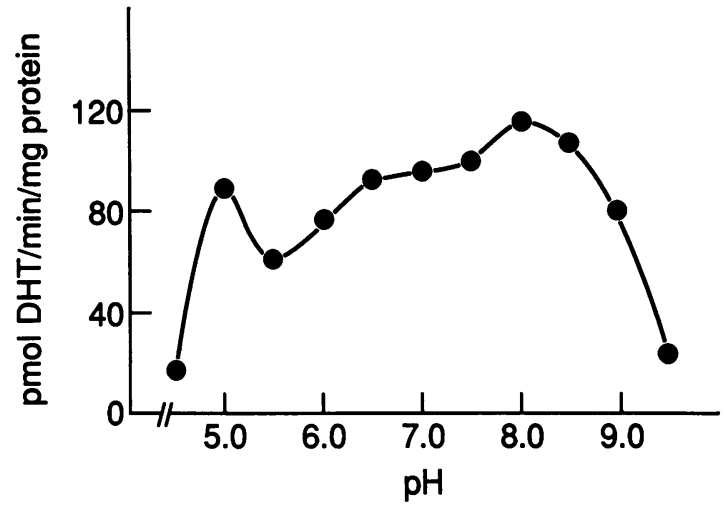

Figure 5. Mixing of prostate and transfected COS cell extracts reveals two steroid $5 \alpha$-reductase activities with different pH optima. Extracts were prepared as described in Methods. Approximately $250 \mu \mathrm{g}$ of the prostate extract were mixed with $50 \mu \mathrm{g}$ of the transfected COS cell extract and incubated on ice for $5 \mathrm{~min}$ before assay in $0.1 \mathrm{M}$ Tris-citrate buffer at the indicated $\mathrm{pH}$. The assay was carried out for 20 min at $37^{\circ} \mathrm{C}$ in a volume of $0.5 \mathrm{ml}$ in the presence of $10 \mu \mathrm{M}\left[{ }^{14} \mathrm{C}\right]-$ testosterone substrate and $10 \mathrm{mM}$ NADPH cofactor. After termination of the reactions, conversion of testosterone into dihydrotestosterone was determined by thin-layer chromatography.

extracts prepared from a single prostate and from a single COS cell transfection experiment. These assays were carried out at the $\mathrm{pH}^{3}$ optima of the individual enzymes ( $\mathrm{pH} 7.0$ for the enzyme encoded by the cDNA, and pH 5.0 for the prostate enzyme). The data of Fig. $6 A$ indicate that the cDNA-encoded enzyme demonstrated an apparent $K_{\mathrm{i}}$ for finasteride (MK-906) of $\sim 300 \mathrm{nM}$. The prostate enzyme was much more sensitive to this inhibitor, with a $K_{\mathrm{i}}$ value of $\sim 3 \mathrm{nM}$ (Fig. $6 \mathrm{~B}$ ).

We next carried out the mixing experiment shown in Fig. 7. The narrow $\mathrm{pH}$ optimum and the low enzyme activity of the prostate enzyme (Fig. $4 \mathrm{~B}$ ) made it necessary to perform these experiments at $\mathrm{pH}$ 5.0. Initially, an $\mathrm{IC}_{50}$ value for finasteride was determined for the individual extracts. The COS cell extract containing the cloned enzyme demonstrated an $\mathrm{IC}_{50}$ value of $10 \mu \mathrm{M}$, whereas enzyme activity in the prostate demonstrated an $\mathrm{IC}_{50}$ value of $10 \mathrm{nM}$ for finasteride (MK-906) (Fig. 7). When aliquots of the two extracts that contained equal amounts of steroid $5 \alpha$-reductase activity were mixed, the inhibition curve was biphasic (Fig. 7), indicating the presence of two enzymes having $\mathrm{IC}_{50}$ values of $\sim 10 \mathrm{nM}$ and $10 \mu \mathrm{M}$, and presumably corresponding to the prostate and cDNA-encoded enzymes, respectively.

\section{Discussion}

We report molecular, genetic, biochemical, and pharmacological evidence for more than one steroid $5 \alpha$-reductase activity in man. Molecular cloning and Southern blotting experiments with genomic DNA from subjects with steroid $5 \alpha$-reductase deficiency failed to detect mutations in a previously cloned gene in five unrelated affected individuals. The analysis of two RFLPs similarly excluded this locus as being responsible for the disease in five other affected individuals. Biochemical experiments indicated that the enzyme encoded by the cDNA had a neutral to basic $\mathrm{pH}$ optima, whereas the predominant enzyme activity in the prostate demonstrates an acidic optima. 

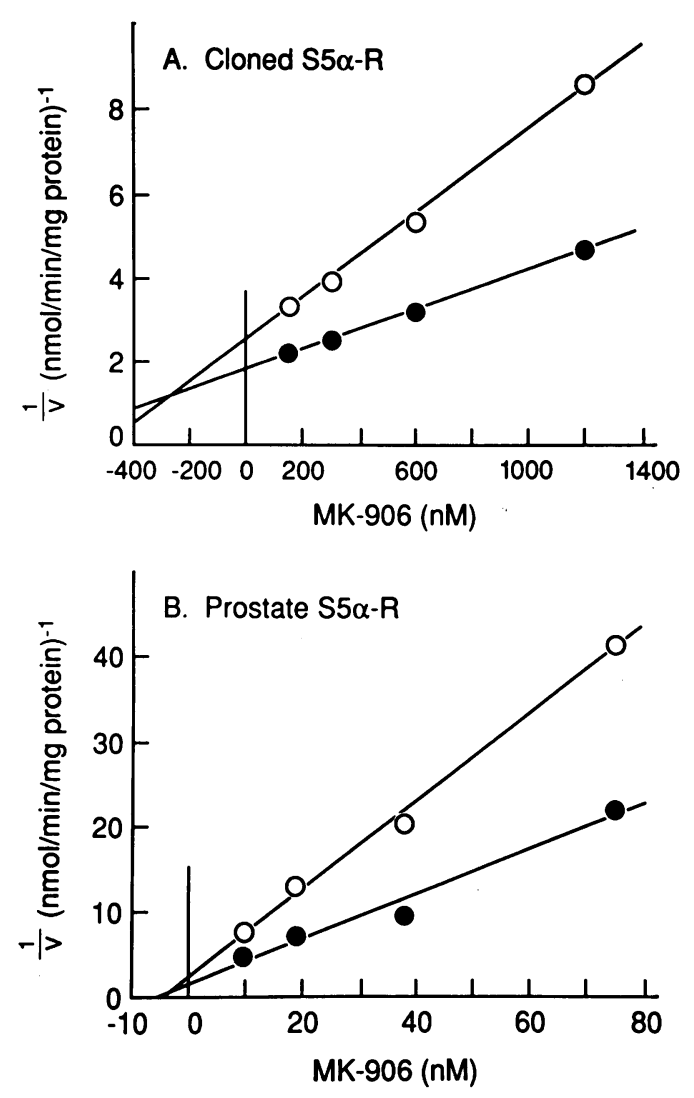

Figure 6. Inhibition of cDNA-encoded (Cloned $S 5 \alpha-R$ ) and prostate steroid $5 \alpha$-reductase (Prostate $S 5 \alpha-R$ ) enzymes by finasteride (MK906). Transfected COS cell and prostate extracts were prepared and assayed (at pH 7.0 for cDNA-encoded enzyme, and pH 5.0 for prostate enzyme) as described in Methods. Approximately $50 \mu \mathrm{g}$ of the COS cell extract $(A)$ and $100 \mu \mathrm{g}$ of the prostate extract $(B)$ were assayed at either $2 \mu \mathrm{M}$ (open circles) or $4 \mu \mathrm{M}$ (closed circles) $\left[{ }^{14} \mathrm{C}\right]-$ testosterone in the presence of the indicated concentrations of the drug. Data from duplicate reactions were analyzed on an IBM PC AT computer using a linear regression program obtained from J. Metherall (Department of Molecular Genetics, University of Texas Southwestern Medical Center, Dallas, Texas). In both panels, the $K_{\mathrm{i}}$ for MK-906 is defined by the intersection of the two lines (28). The results are representative of more than two independent experiments.

Finally, the enzyme encoded by the cDNA is only weakly inhibited by the 4-aza steroid finasteride (MK-906), whereas the prostate enzyme is markedly inhibited by this compound. In toto, the results of these multiple lines of investigation support the existence of at least two steroid $5 \alpha$-reductase enzymes in man.

Of the experiments reported here, the molecular genetic evidence is especially supportive of this conclusion. In these studies, we failed to find mutations in the coding region of the gene in four patients with known biochemical abnormalities. More importantly, analysis of two RFLPs led to the finding of heterozygosity at the cloned locus in seven patients from isolated populations or of known consanguineous descent (individuals 526, 41, 338, NG2-4, and 904 of Table II). Because steroid $5 \alpha$-reductase deficiency is inherited in an autosomal recessive fashion $(2,3)$, affected individuals from such inbred matings must be homozygous for the mutant allele causing the disease (29). Similarly, in an outbred family, multiple affected individuals must have the same genotype for a given marker at

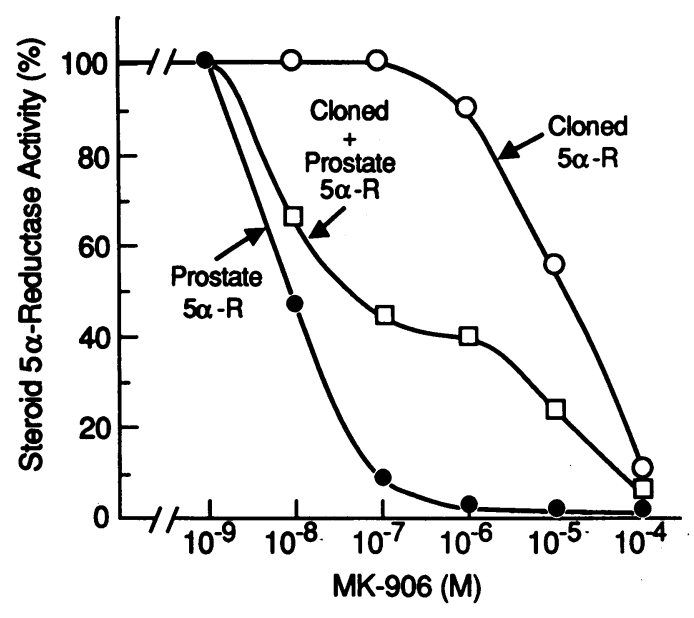

Figure 7. Mixing of prostate and transfected COS cell extracts reveals two steroid $5 \alpha$-reductase activities with different IC $_{50}$ values for finasteride (MK-906). Transfected COS cell and prostate extracts were prepared as described in Methods. Approximately $50 \mu \mathrm{g}$ of the prostate extract (closed circles), $500 \mu \mathrm{g}$ of the COS cell extract (open circles), or $50 \mu \mathrm{g}$ of the prostate extract plus $500 \mu \mathrm{g}$ of the COS cell extract (open squares) were assayed at $\mathrm{pH} 5.0$ in a volume of $0.5 \mathrm{ml}$ for $20 \mathrm{~min}$ at $37^{\circ} \mathrm{C}$ in the presence of $1 \mu \mathrm{M}\left[{ }^{14} \mathrm{C}\right]$ testosterone and the indicated concentrations of the drug. For the mixing experiment, COS cell and prostate extracts were combined and incubated on ice $5 \mathrm{~min}$ before assay. The reactions were subjected to thin-layer chromatography to measure conversion of testosterone into dihydrotestosterone. Steroid $5 \alpha$-reductase activity in the absence of MK-906 was assigned a value of $100 \%$ for all extracts.

the true disease gene, although in contrast to the situation in a consanguineous mating, these individuals could be either homozygous or heterozygous for this marker (29). This result was not found in the outbred family studied here (Fig. 2).

The genotyping results thus violate genetic tenets of autosomal recessive inheritance and effectively exclude the cloned locus as being the disease gene in steroid $5 \alpha$-reductase deficiency. This exclusion in turn eliminates possibilities such as differential splicing (30), RNA editing (31), alternate translational reading frames (32), and ribosome frameshifting (33), as explanations for the absence of mutations in the subjects whose genes were sequenced. If these posttranscriptional events occurred, then the disease would still segregate with the cloned gene.

Both the genetic results and the biochemical and pharmacological experiments support the existence of more than one steroid $5 \alpha$-reductase activity in man. However, the experiments do not distinguish between the presence of a novel steroid $5 \alpha$-reductase enzyme in tissues such as the prostate, versus the presence of a second subunit in this tissue that complexes with and alters the properties of the enzyme encoded by the cDNA.

In considering these two possibilities, we note that the subunit structure of steroid $5 \alpha$-reductase has not yet been experimentally determined owing to difficulties in solubilizing and purifying the active enzyme (34). However, both the cloned human and rat cDNAs have been expressed as active enzymes in mammalian cells (12), the yeast Saccharomyces cerevisiae (Thigpen, A. E., and D. W. Russell, unpublished observations), and Escherichia coli (35). These results suggest that if a second subunit is required for activity, it must be evolutionarily con- 
served among these diverse species. Furthermore, transfection of the human cDNA into mammalian cells that contain little or no endogenous steroid $5 \alpha$-reductase activity results in the expression of an active enzyme (Andersson, S., and D. W. Russell, unpublished observations). Barring a preexisting pool of a putative second subunit, these results support the notion that the cDNAs of and by themselves encode steroid $5 \alpha$-reductase.

It remains possible that the human prostate and select other tissues express a protein or second subunit that affects the biochemical and pharmacological properties of the steroid $5 \alpha$-reductase encoded by the cDNA. The existence of such a protein could explain the absence of an enzyme with a neutral to basic pH optima in prostate extracts (Fig. $4 \mathrm{~B}$ ), despite the fact that this tissue contains the mRNA from which the cloned cDNA was derived (12). The cDNA was isolated multiple times from two different prostate cDNA libraries (12), and blot hybridization studies carried out at high stringency revealed a prostate mRNA identical in size to the full-length cDNA (12). Similarly, polymerase chain reactions performed on mRNA isolated from the prostate assayed in Fig. $4 \mathrm{~B}$ also indicated the presence of this mRNA (Berman, D. M., and D. W. Russell, unpublished observations).

Although these data are consistent with a second tissue-specific subunit hypothesis, an alternate explanation is that the mRNA corresponding to the cloned cDNA is present, but expressed only at low levels in the prostate. Support for this latter explanation comes from an analysis of the structure of the cDNA. This region contains two and possibly three methionine codons at the 5 ' end of the mRNA, only one of which specifies the start of the steroid $5 \alpha$-reductase enzyme $(12,13)$. Transfection studies with the cDNA revealed that the presence of one of these upstream methionine codons caused a 10-fold reduction in the expression of steroid $5 \alpha$-reductase, presumably by inhibiting translation of the downstream reading frame encoding the enzyme (12). These findings support the idea that although mRNA complementary to the cloned cDNA is present in the prostate, it may be inefficiently translated, leading to a low level of the protein.

Our results do not formally exclude the possibility of a prostate-specific posttranslational modification of the protein encoded by the steroid $5 \alpha$-reductase cDNA. However, it seems unlikely that the absence of such a modification in steroid $5 \alpha$ reductase-deficient individuals could give rise to enzymes with no activity, abnormal $K_{\mathrm{m}}$ 's for NADPH and testosterone, and an unstable enzyme (Table I). In addition, the phenotype of these subjects relates almost exclusively to improper sexual development (3), suggesting that if a modification enzyme such as a protein kinase or methylase is defective in these subjects, it would have to be specific for steroid $5 \alpha$-reductase.

The data presented here raise the broader questions of what is the function of the steroid $5 \alpha$-reductase encoded by the cDNA in humans and does it contribute to androgen physiology? Along these latter lines, it is interesting to note that the levels of $5 \alpha$-reduced steroids in steroid $5 \alpha$-reductase-deficient subjects or in individuals treated with MK-906 never reach zero $(2,3,36)$, suggesting that the cloned gene may well have a physiological function. It is also unknown whether humans are unique in having more than one steroid $5 \alpha$-reductase. The answers to these questions and those concerning the proteins responsible for the multiple activities may come from additional cloning studies. To these ends, we have recently isolated a second human steroid $5 \alpha$-reductase cDNA from prostate by ex- pression cloning (Andersson, S., et al., unpublished observations). Experiments are currently in progress to analyze the molecular genetics of this gene in steroid $5 \alpha$-reductase deficiency.

\section{Acknowledgments}

We thank Diane R. Allman, Lisa Beatty, Jeffry Cormier, Daphne Davis, Lavon Sanders, and Edith Womack for excellent technical assistance, and Drs. M. S. Brown, T. Gautier, H. H. Hobbs, J. L. Goldstein, J. McConnell, D. C. Gajdusek, and G. Rasmusson for supplies, advice, or critical reading of the manuscript. Special thanks to Dr. Anne Bowcock for her patient genetic tutelage.

This research was supported by grants GM-43753 (to D. W. Russell) and DK-03892 (to J. D. Wilson) from the National Institutes of Health, and by grant I-0971 (to D. W. Russell) from the Robert A. Welch Foundation. E. P. Jenkins is supported by a training grant (DK07307) from the National Institutes of Health.

\section{References}

1. Wilson, J. D. 1975. Metabolism of testicular androgens. Handb. Physiol. 5:491-508.

2. Imperato-McGinley, J., and T. Gautier. 1986. Inherited $5 \alpha$-reductase deficiency in man. Trends Genet. 2:130-133.

3. Griffin, J. E., and J. D. Wilson. 1989. The androgen resistance syndromes: $5 \alpha$-reductase deficiency, testicular feminization, and related disorders. In The Metabolic Basis of Inherited Disease. C. R. Scriver, A. L. Beaudet, W. S. Sly, and D. Valle, editors. McGraw-Hill Inc., New York. 1919-1944.

4. Moore, R. J., and J. D. Wilson. 1972. Localization of the reduced nicotinamide adenine dinucleotide phosphate: $\Delta^{4}-3$-ketosteroid $5 \alpha$-oxidoreductase in the nuclear membrane of the rat ventral prostate. J. Biol. Chem. 247:958-967.

5. Schneider, J. J. 1952. Conversion of desoxycorticosterone to four allopregnane metabolites by rat liver in vitro. J. Biol. Chem. 199:235-244.

6. McGuire, J. S., Jr., and G. M. Tomkins. 1960 . The heterogeneity of $\Delta^{4}-3-k e-$

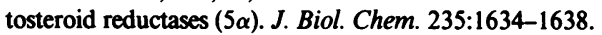

7. Moore, R. J., and J. D. Wilson. 1976. Steroid $5 \alpha$-reductase in cultured human fibroblasts. J. Biol. Chem. 251:5895-5900.

8. Bruchovsky, N., P. S. Rennie, F. H. Batzold, S. L. Goldenberg, T. Fletcher, and M. G. McLoughlin. 1988. Kinetic parameters of $5 \alpha$-reductase activity in stroma and epithelium of normal, hyperplastic, and carcinomatous human prostates. J. Clin. Endocrinol. \& Metab. 67:806-816.

9. Itami, S., S. Kurata, T. Sonoda, and S. Takayasu. 1991. Characterization of $5 \alpha$-reductase in cultured human dermal papilla cells from beard and occipital scalp hair. J. Invest. Dermatol. 96:57-60.

10. Moore, R. J., J. E. Griffin, and J. D. Wilson. 1975. Diminished $5 \alpha$-reductase activity in extracts of fibroblasts cultured from patients with familial incomplete male pseudohermaphroditism, type 2. J. Biol. Chem. 251:7168-7172.

11. Andersson, S., R. W. Bishop, and D. W. Russell. 1989. Expression cloning and regulation of steroid $5 \alpha$-reductase, an enzyme essential for male sexual differentiation. J. Biol. Chem. 264:16249-16255.

12. Andersson, S., and D. W. Russell. 1990. Structural and biochemical properties of cloned and expressed human and rat steroid 5 $\alpha$-reductases. Proc. Natl. Acad. Sci. USA. 87:3640-3644.

13. Jenkins, E. P., C.-L. Hsieh, A. Milatovich, K. Normington, D. M. Berman, U. Francke, and D. W. Russell. 1991. Characterization and chromosomal mapping of human steroid $5 \alpha$-reductase gene and pseudogene and mapping of the mouse homologue. Genomics. 11:1102-1112.

14. Wilson, J. D. 1975. Dihydrotestosterone formation in cultured human fibroblasts. J. Biol. Chem. 250:3498-3504.

15. Peterson, R. E., J. Imperato-McGinley, T. Gautier, and E. Sturla. 1977. Male pseudohermaphroditism due to steroid $5 \alpha$-reductase deficiency. Am. J. Med. 62:170-191.

16. Leshin, M., J. E. Griffin, and J. D. Wilson. 1978. Hereditary male pseudohermaphroditism associated with an unstable form of $5 \alpha$-reductase. J. Clin. Invest. 62:685-691.

17. Imperato-McGinley, J., R. E. Peterson, M. Leshin, J. E. Griffin, G. Cooper, S. Draghi, M. Berenyi, and J. D. Wilson. 1980. Steroid $5 \alpha$-reductase deficiency in a 65-year-old male pseudohermaphrodite: the natural history, ultrastructure of the testes, and evidence for inherited enzyme heterogeneity. J. Clin. Endocrinol. \& Metab. 50:15-22.

18. Price, P., J. A. H. Wass, J. E. Griffin, M. Leshin, M. O. Savage, D. M. Large, D. E. Bu'Lock, D. C. Anderson, J. D. Wilson, and G. M. Besser. 1984. 
High dose androgen therapy in male pseudohermaphroditism due to $5 \alpha$-reductase deficiency and disorders of the androgen receptor. J. Clin. Invest. 74:14961508.

19. Johnson, L., F. W. George, W. B. Neaves, I. M. Rosenthal, R. A. Christensen, A. Decristoforo, H.-U. Schweikert, M. V. Sauer, M. Leshin, J. E. Griffin, and J. D. Wilson. 1986. Characterization of the testicular abnormality in $5 \alpha$-reductase deficiency. J. Clin. Endocrinol. \& Metab. 63:1091-1099.

20. Lehrman, M. A., W. J. Schneider, T. C. Südhof, M. S. Brown, J. L. Goldstein, and D. W. Russell. 1985. Mutation in LDL receptor: Alu-alu recombination deletes exons encoding transmembrane and cytoplasmic domains. Science (Wash. DC). 227:140-146.

21. Saiki, R. K., D. H. Gelfand, S. Stoffel, S. J. Scharf, R. Higuchi, G. T. Horn, K. B. Mullis, and H. A. Erlich. 1988. Primer-directed enzymatic amplification of DNA with a thermostable DNA polymerase. Science (Wash. DC). 239:487-491.

22. Maxam, A. M., and W. Gilbert. 1980. Sequencing end-labeled DNA with base-specific chemical cleavages. Methods Enzymol. 65:499-560.

23. Sambrook, J., E. F. Fritsch, and T. Maniatis. 1989. Molecular Cloning: A Laboratory Manual. Cold Spring Harbor Laboratory, Cold Spring Harbor, NY. $1-18.8$.

24. Sanger, F., S. Nicklen, and A. R. Coulson. 1977. DNA sequencing with chain-terminating inhibitors. Proc. Natl. Acad. Sci. USA. 74:5463-5467.

25. Messing, J. 1983. New M13 vectors for cloning. Methods Enzymol. 101:20-78.

26. Liang, T., M. A. Cascieri, A. H. Cheung, G. F. Reynolds, and G. H. Rasmusson. 1985. Species differences in prostatic steroid $5 \alpha$-reductases of rat, dog, and human. Endocrinology. 117:571-579.
27. Imperato-McGinley, J., M. Miller, J. D. Wilson, R. E. Peterson, C. Shackleton, and D. C. Gajdusek. 1991. A cluster of male pseudohermaphrodites with $5 \alpha$-reductase deficiency in Papua New Guinea. Clin. Endocrinol. 34:293-298.

28. Segel, I. H. 1975. Behavior and analysis of rapid equilibrium and steadystate enzyme systems. In Enzyme Kinetics. Wiley \& Sons, New York. 1-957.

29. Vogel, F., and A. G. Motulsky. 1986. Human Genetics: Problems and Approaches. 2nd ed. Springer-Verlag, Berlin. 1-807.

30. Padgett, R. A., P. J. Grabowski, M. M. Konarska, S. Seiler, and P. A. Sharp. 1986. Splicing of messenger RNA precursors. Annu. Rev. Biochem. 55:1119-1150.

31. Weiner, A. M., and N. Maizels. 1990. RNA editing: guided but not templated? Cell. 61:917-920.

32. Shaw, M. W., P. W. Choppin, and R. A. Lamb. 1983. A previously unrecognized influenza B virus glycoprotein from a bicistronic mRNA that also encodes the viral neuraminidase. Proc. Natl. Acad. Sci. USA. 80:4879-4883.

33. Atkins, J. F., R. B. Weiss, and R. F. Gesteland. 1990. Ribosome gymnastics. Degree of difficulty 9.5, style 10.0. Cell. 62:413-423.

34. Frederiksen, D. W., and J. D. Wilson. 1971. Partial characterization of the nuclear reduced nicotinamide adenine dinucleotide phosphate: $\Delta^{4}$-3-ketosteroid $5 \alpha$-oxidoreductase of rat prostate. J. Biol. Chem. 246:2584-2593.

35. Harris, G. S., and B. A. Azzolina. 1990. 5 $\alpha$-reductase, a mammalian membrane-bound protein: cloning and expression in Escherichia coli. FASEB (Fed. Am. Soc. Exp. Biol.) J. 4:2717a. (Abstr.)

36. Vermeulen, A., V. A. Giagulli, P. D. De Schepper, A. Buntinx, and E. Stoner. 1989. Hormonal effects of an orally active 4-azasteroid inhibitor of $5 \alpha$-reductase in humans. Prostate. 14:45-53. 